\title{
Inflation Hedging Properties of Different Asset Classes in Malaysia
}

\author{
Siew-Peng Lee* and Mansor Isa
}

\begin{abstract}
Manuscript type: Research paper

Research aims: The objective of this study is to examine the inflation hedging properties of various asset classes (stock, gold, real estate, Treasury bond and Treasury bill) in the Malaysian context.

Design/Methodology/Approach: This is an empirical analysis using quarterly data from the period of 1980 to 2016. The Autoregressive Distributed Lag (ARDL) bounds cointegration model is used for testing the long-run relationship while the error correction model (ECM) is used for testing the short-run dynamics.

Research findings: Our results show that stocks and government bonds in Malaysia can provide a complete hedge against inflation in the long-run while real estate shows partial hedging evidence. Gold and Treasury bills, however, are not inflation hedges. For the shortrun, stocks, gold and real estate show evidence of rapid adjustment to changes in inflation while government securities indicate a mild adjustment.

Theoretical contributions/Originality: First, this study provides new evidence on inflation hedges from the perspective of an emerging market. Second, this study uses the ARDL and ECM approach to study the long-run and short-run dynamics of asset returns and inflation. This is in contrast to many previous studies that mainly used the Ordinary Least-Squares (OLS) analysis. Third, this study is important for the Malaysian market because previous studies in
\end{abstract}

\footnotetext{
* Corresponding author: Siew-Peng Lee is a Lecturer at the Universiti Tunku Abdul Rahman, Malaysia. Email: leesp@utar.edu.my

Mansor Isa is a Director at the University of Malaya Centre for Continuing Education (UMCCed) and formerly a Professor at the Faculty of Business and Accountancy, University of Malaya, Kuala Lumpur, Malaysia. Email: Mansor.isa@um.edu.my
}

https://doi.org/10.22452/ajba.vol12no1.8 
Malaysia had merely focussed on stock returns and inflation. This study broadens the scope by including different asset classes.

Practitioner/Policy implications: The implication to investors and fund managers is that they should consider stocks, real estate and Treasury bonds in their investment portfolios, given that these asset returns offer satisfactory protection against inflation.

Research limitations/Implications: The result discussed in this study may be specific to the data and methodology employed in the analysis; thus, it is not applicable to other periods nor other emerging markets. Future studies on inflation hedges may consider a comparative study of a cross-section of countries or use an expanded array of assets in the analysis.

Keywords: Fisher Effect, Inflation Hedges, ARDL Bounds Tests, Malaysia

JEL Classification: G12, G18

\section{Introduction}

One important question faced by investors is whether the return of their investments protect them against inflation. The issue of investment returns and inflation can be traced back to Fisher (1930) who proposed a theory of the relationship between inflation and interest rates. Fisher decomposed nominal interest rates into real rates and expected inflation. The expected real rate was determined by real factors such as capital productivity and investors' time and risk preferences. Therefore, these are independent of the monetary sectors. Real rate and expected inflation should be independent of each other, thereby resulting in a direct relationship between nominal rates and inflation. Over time, the enquiry on Fisher's hypothesis has been extended to include returns on various financial assets as well as physical assets such as stocks, bonds, bills, bank deposits, human capital, real estate and gold. The testable hypothesis of the theory is that asset returns and expected inflation should have a direct relationship. When there is a perfect correlation between the two, we can conclude that the asset is a complete hedge against inflation. Investors would be fully compensated for the upward movements in the general price level when there is a corresponding increase in the nominal asset returns. However, empirical studies looking at the relationship between nominal interest rates and inflation have yielded mixed results.

Arnold and Auer (2015) speculated that the lack of consensus in the findings may be due to the uniqueness of each study in terms 
of methodology and study samples. It was mentioned that to obtain a clear answer on inflation hedging, the process has to simultaneously, include all asset classes (stock, gold, real estate and fixed income securities) so as to allow a direct comparison of results which can then detect which asset can be the best hedge. Taking up this suggestion, the current study aims to examine the inflation hedging properties of various asset classes in Malaysia which include stocks, gold, real estate, Treasury bond and Treasury bill. The motivation for this study is that investors in various investable assets need to know if the return on their investments provides a hedge against inflation. There is a dearth of literature on this topic to help investors to understand the relationship between investment returns and inflation. This study fills that gap. A second motivation is drawn from the theoretical perspective in that this study may be considered a revisit of an old issue. Although the topic on inflation hedging has been studied for a long time, the findings are mixed. Due to the passage of time, it may be worth revisiting the issue to see if the Fisher relationship explains the current situation in Malaysia.

There are three main contributions of this study. First, this study provides new evidence on the issue of inflation hedging from the perspective of an emerging market, Malaysia, which is a relatively small emerging market. It has an economic and market environment that is different from developed markets where most studies have been conducted (for example, Kim \& Ryoo, 2011; Beckmann \& Czudaj, 2013; Tsong \& Lee, 2013; Wang, Lee, \& Thi, 2013). The focus on Malaysia will, therefore, offer a fresh insight into this topic. Second, this study uses the Autoregressive Distributed Lag (ARDL) and error correction model (ECM) approach to study the long-run and short-run dynamics of asset returns and inflation. This is unlike many previous studies which had mainly used the OLS analysis. Third, there is a relatively small number of studies (Gan, 1992; Ibrahim, 2011; Lee, 2014; Yeap \& Lean, 2017) looking at inflation hedging in Malaysia and of those that do, the results have been mixed. Moreover, these studies mainly analysed a single asset return over a relatively short horizon. Our study uses an extended and updated dataset extracted from Malaysia, in comparison to previous studies. We choose to include all the available asset classes (stocks, gold, real estate, Treasury bond and Treasury bill) simultaneously, in order to allow a direct comparison of the results so as to identify which of these assets can be regarded to be the best inflation hedge. 
The remainder of this paper is organised as follows: Section 2 discusses previous studies on asset returns as inflation hedges. Section 3 discusses the data and the ARDL methodology. Section 4 presents and discusses the results and Section 5 concludes the study.

\section{Literature Review}

\subsection{Stock Returns}

From a general economic perspective, stock returns and inflation should be positively related. This is because stock returns are derived from real economic activities whose growth should include elements of inflation. However, empirical studies seemed to show mixed results. For example, the early studies (Lintner, 1975; Jaffe \& Mandelker, 1976; Bodie, 1976; Nelson, 1976; Fama \& Schwert, 1977; Gultekin, 1983a) focussing on US stock returns and inflation showed results that were inconsistent with the Fisher hypothesis. These studies reported that stock returns were negatively correlated with expected and unexpected inflation. Fama (1981) rationalised the findings by proposing that inflation negatively affects stock returns via real economic activities. In the first instance, it is proposed that inflation and real economic activities are negatively related but in the second instance, it is proposed that real economic activities and stock returns are positively related. When both these propositions are true, inflation and stock prices would be negatively related. Geske and Roll (1983) discussed the negative relationship of the fiscal and monetary linkages between inflation and stock prices. They noted that when there is an economic slowdown, there will also be a decrease in government revenues. This would result in an increase in the fiscal deficit. To address this deficit, the central bank acts by increasing the money supply, hence, inflation.

Interestingly, Gultekin (1983a) and Gultekin (1983b) yielded opposing results. Using the monthly data gathered from across 26 international markets, Gultekin (1983a) found a negative relationship between stock returns and inflation. The finding was consistent with many other studies of around the same time. In a subsequent study, Gultekin (1983b) used the semi-annual and annual data of the DJIA and S\&P 500 indices to examine the same phenomenon. The results generated were consistent with stock returns being effective inflation hedges. This outcome was verified by many subsequent studies such as Boudoukh and Richardson (1993) who focussed on the US and UK, Solnik and Solnik (1997) who 
looked at the US, several European markets and Japan, Anari and Kolari (2001) who studied the US and major world markets, Engsted and Tanggaard (2002) who studied the US and Denmark, and Kim and Ryoo (2011) who also focussed on the US. The results drawn from all these studies seemed quite robust when compared to data taken from different markets and also when different methodologies were applied. Most studies have been using the cointegration, VAR and causality analysis apart from the usual OLS analysis. Anari and Kolari's (2001) study found that inflation has a negative short-run effect on stock returns but a positive long-run relation. There was also some disagreement with regard to the impact of data frequency on inflation hedges. For instance, Boudoukh and Richardson (1993) observed that longer frequency leads to better hedging quality whereas Engsted and Tanggaard (2002) detected contradicting results.

Alagidede and Panagiotidis (2010) studied several African markets by using the OLS and cointegration techniques. They noted that, in general, stocks do provide an inflation hedge. In the context of Asian markets, Zhao (1999) found a negative relationship between stock returns and inflation in China. In the Malaysian context, Gan (1992) and Ibrahim (2011) discovered contradicting results. While Gan found a negative impact of expected inflation on real stock returns, Ibrahim's (2011) finding confirmed Fisher's hypothesis with respect to the Malaysian stock return for the pre-Asian financial crisis period (19881996) but not for the post-crisis period. Using quarterly data, Rushdi, Kim and Silvapulle (2012) found that Australian stocks served as an effective hedging instrument against expected inflation. The study by Pimentel and Choudhry (2014) which looked at the Brazil market also found a positive relationship between stock returns and inflation. Looking at Pakistan, Tiwari, Dar, Bhanja, Arouri and Teulon (2015) and Shahbaz, Islam and Rehman (2016) confirmed that stock is a good hedge against inflation, both in the long-run and short-run.

\subsection{Gold}

Gold is a special asset in the sense that it has its own value. This makes gold stand apart from other financial assets analysed in this study. The value of gold is in its price; it is not dependent on its expected cash flows. Gold analysts argue that gold prices should move in a positive manner with inflation. The examination of gold returns in relation to inflation had only been a recent study when compared to other financial 
assets. Earlier studies looking at gold include Chua and Woodward (1982) who used the monthly and semi-annual data of five developed markets including the US and the UK. They found mixed outcomes. Brown and Howe (1987) also used the monthly data of the US market and they too discovered that gold did not provide protection against inflation. Mahdavi and Zhou (1997), Tully and Lucey (2007) and Wang, Lee and Thi (2011) also documented the insignificant long-run relationship between gold returns and the US inflation. They asserted that the rigidity between the consumer price index and the price of gold affected the inflation hedging ability of gold in the long-run. However, there were studies that documented differing results. Ghosh, Levin, Macmillan and Wright (2004), Levin, Montagnoli and Wright (2006), McCown and Zimmerman (2006), Worthington and Pahlavani (2007), Joy (2011) and Beckmann and Czudaj (2013) all revealed that there was a long-run positive relationship between gold price and inflation in the US market. This outcome was confirmed by Wang et al. (2013) and Bampinas and Panagiotidis (2015).

However, when focussing on the Japan market, Wang et al. (2013) found that the gold returns were unable to hedge against inflation. Looking at the Pakistan market, Shahbaz, Tahir, Ali and Rehman (2014) observed that gold was a good hedge against inflation in the short-run and long-run. The outcome was different for Malaysia where Ghazali, Lean and Bahari (2015) documented no significant relationship between gold returns and inflation. In a recent study, Aye, Carcel, Gil-Alana and Gupta (2017) examined the inflation ability of gold in the UK. They used annual data collected over the period of 1257-2016. Using the fractional integration approach, they found that gold price and inflation moved together in the long-run. This means that gold has an inflation hedging ability.

\subsection{Real Estate}

Real estate is often regarded as a good protection against inflation. In general, many prior studies support the Fisher hypothesis which states that real estate returns move together with inflation. Some early evidence was provided by Fama and Schwert (1977) who found that the US residential real estate provided a complete hedge against inflation. Similarly, Ibbotson and Siegel (1984), Miles and Mahoney (1997) and Anari and Kolari (2002) also confirmed the hedging capabilities of real estate. The same outcome was noted in the UK where Limmack and 
Ward (1988) and later, Blake, Goodwin, McIntosh and Simmons (2010) revealed that real estate acted as a hedge against inflation.

Nonetheless, the US and UK markets are not the only markets where the inflation hedging ability of real estate had been detected. Chen and Foo (2006) investigated the international real estate markets of Hong Kong, Tokyo, Singapore, Taipei and London. They found that the inflation hedging features of real estate exist but the degree varied significantly across the different markets. Surprisingly, China's real estate does not seem to provide a hedge against inflation as uncovered by Chu and Sing (2004) and Zhou and Clements (2010). In the context of Taiwan, Fang, Wang and Nguyen (2008) used monthly data to examine Taiwan's real estate prices over the period of 19912006. They found a negative relationship between house prices and inflation. Gunasekarage, Power and Ting Zhou (2008) focussed on New Zealand and Lee (2014) examined Malaysia. Both studies found that real estate does provide an effective hedge against inflation. However, in a recent study, Yeap and Lean (2017) found that housing investment in Malaysia does not provide an inflation hedge to investors. These inconsistent results between Lee (2014) and Yeap and Lean (2017) may be attributed to the different methodologies used although their study periods overlapped significantly. Lee (2014) employed the Fama and Schwert model and the dynamic OLS to analyse house price data over the period of 1999-2012. In contrast, Yeap and Lean (2017) adopted the NARDL approach to examine house price data over the period of 1999-2015. Most of these studies suggest that housing assets investment cannot hedge against inflation in the short-run, therefore, it is important to revisit the linkage between house prices and inflation by increasing the study period (data of a longer period) and using a different methodological approach.

\subsection{Fixed Income Securities}

Studies on fixed income securities and inflation are largely limited to Treasury bill and Treasury bond. In general, earlier studies found only limited support for the Fisher hypothesis for Treasury bill rates. Fama (1975) examined 1 to 6 months US Treasury bill rates and inflation. His findings confirmed the Fisher hypothesis for the short-run. Mishkin (1992) and Fahmy and Kandil (2003) also found evidence to support that Treasury bill rates are inconsistent with the short-run Fisher relationship. However, they found a long-run relation between interest rates and 
inflation. Meanwhile, Lee, Clark and Ahn (1998) detected evidence of the Fisher effect, both in the short-run and long-run, for the US Treasury bill. In a recent study, Tsong and Lee (2013) disclosed evidence supporting the Fisher hypothesis in six OECD markets (Australia, Belgium, Canada, Sweden, the US and UK). Their upper quantiles cointegration showed that the nominal 3-month Treasury bill rate responded directly to changes in inflation.

Turning to bonds, Fama and Schwert (1977) were also able to present evidence in support of the Fisher hypothesis. Likewise, Smirlock (1986) found a significant positive response of long-term bonds to inflation. In another study, Engsted and Tanggaard (2002) observed that the relationship between US bond returns and inflation was positive; it became stronger as the horizon increased. From their study investigating the US government inflation-indexed bonds and inflation for the period of August 1997 to July 2001, Laatsch and Klein (2003) also noted that changes in nominal interest rates were significantly related to changes in expected inflation. However, a contrasting outcome was provided by Al-Khazali (1999) who found that yields on long-term government bond and inflation were not cointegrated in nine Pacific-Basin countries, over the period of 1980-1994.

\section{Data and Methodology}

\subsection{Data and Summary Statistics}

This study uses quarterly data covering the period of 1980-2016. The following asset classes were included: stocks, gold, real estate, bonds and bills. All assets were taken from the data series beginning 1980 except Treasury bonds and gold because data for the Treasury bond yields were only available from 1996 while gold price was only available from 2002. All data were obtained from Datastream (Thomson Reuters), with the exception of gold price and "all house price index". The gold price was obtained from the Malaysian Central Bank's website.

The variable names and their explanations are listed in Table 1. A nominal asset returns (nar) is the change in the price of investment asset from $t$ to $t-1$, expressed in percentage. The FBMKLCI which is the Malaysian equity index, representing a well-diversified equity portfolio, is used to measure the nominal stock returns (nsr). With regards to gold, this study uses the selling price of one troy ounce of domestic gold bullion, known as Kijang Emas, to represent gold price. The "all house 
Inflation Hedging Properties of Different Asset Classes in Malaysia

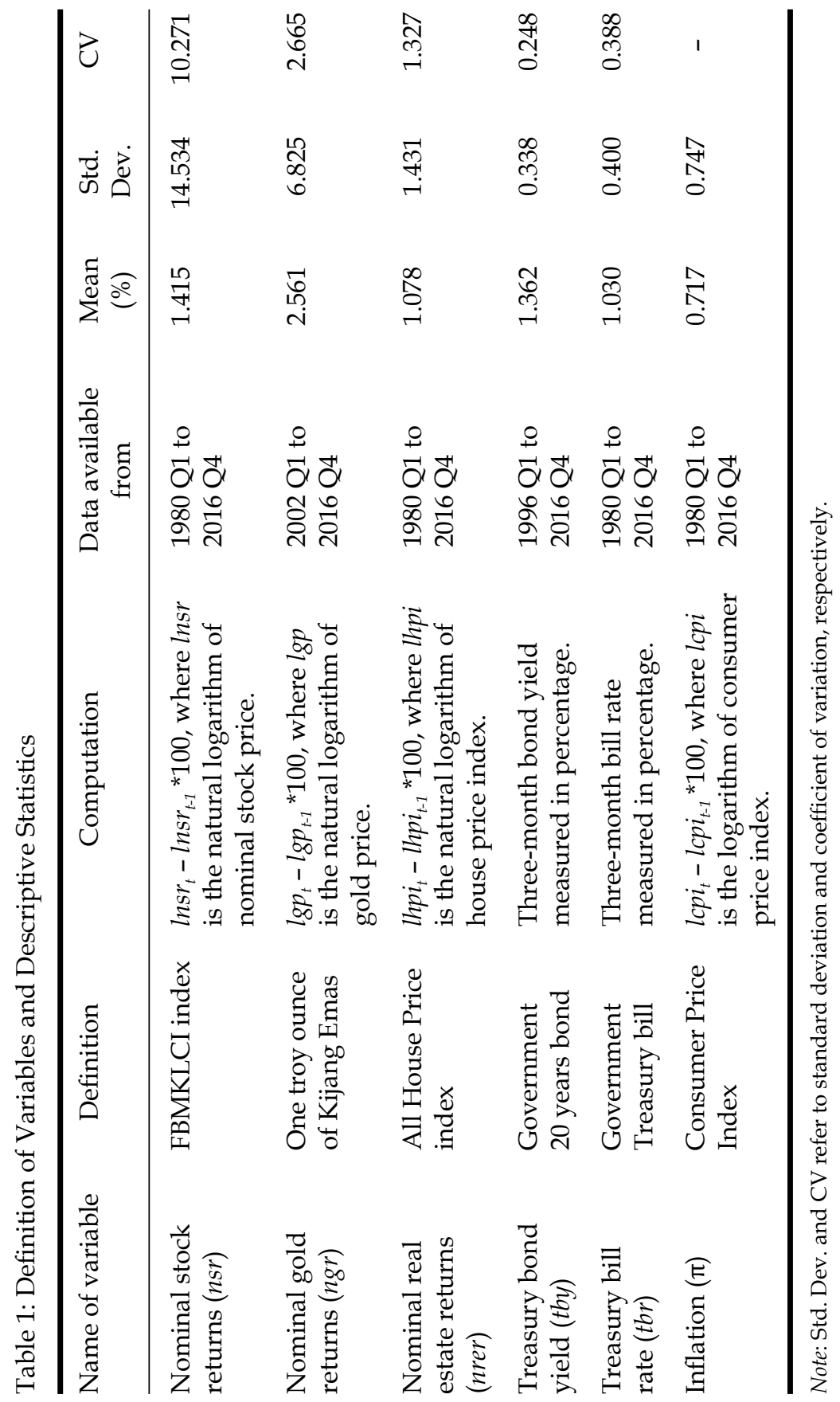


price index" published by the National Property Information Centre (NAPIC) is used to represent the real estate asset price. Treasury bond yields (tby) measured in percentage is used and proxied by the 20-year Malaysia government bonds. The return to Treasury bill is measured by the 3-month to maturity of Malaysia Treasury bill rate (tbr). Finally, the domestic consumer price index (CPI) is used to represent inflation. CPI is the most frequently used indicator of inflation. In this study, the rate of inflation is measured as the percentage change in the CPI.

Table 1 presents the summary statistics of the asset series for the whole sample. The asset with the highest mean return is gold, with 2.561 per cent per quarter. This is followed by stocks, bonds, real estate and bills. The standard deviation shows that the nominal stock returns are the most volatile, followed by gold, real estate and government securities. It is quite surprising that the ordering of the means is inconsistent with their respective standard deviations. For example, while stocks understandably have the highest standard deviation, returns were overshadowed by gold. Real estate also seemed to be performing poorly throughout the study period when compared to government bonds. The last column in Table 1 shows the coefficient of variation $(\mathrm{CV})$ which measures the amount of volatility per unit return. The CV ranked the assets in the following sequence: stocks, gold, real estate, bonds and bills. It should also be noted that Table 1 emphasises that all the asset returns were greater than the mean inflation rate, ${ }^{1}$ which indicates that these assets do protect investors against inflation.

\subsection{Empirical Model}

According to Rushdi et al. (2012), the Fisher equation that is applied to different asset returns can be written as follows:

$$
\operatorname{nar}_{\mathrm{t}}=\alpha+\beta_{\mathrm{mt}}+\varepsilon_{\mathrm{t}}
$$

where $\alpha$ is the intercept, $\varepsilon_{\mathrm{t}}$ is the error term at time $t$, nar represents nominal asset returns earned by holding an investment asset at time $t$, and

\footnotetext{
${ }^{1}$ The fact that inflation rate is low in Malaysia does not invalidate the study because we are testing a theoretical relationship; and inflation, no matter how small, represents an erosion of returns to investors. It should be noted that other studies showing low inflation rates include Lee and Lee (2014), showing the monthly inflation of $0.19 \%$ in the UK, $0.14 \%$ in France, $0.16 \%$ in Germany; and Conlon, Lucey and Uddin (2018) showing the monthly inflation of $0.3 \%$ in the US and $0.2 \%$ in Switzerland and Japan.
} 
$\pi_{t}$ is the rate of inflation in period $t$. The nar is proxied by stock returns, gold returns, real estate returns, and Treasury bond yields and bill rates. The Fisher hypothesis postulates that in equation (1), $\beta=1$ which implies that investment assets can be used as a hedge against inflation.

This study adopts the Autoregressive Distributed Lag (ARDL) bounds testing model for analysis. It is appropriate for small sample testing (Pesaran, Shin, \& Smith, 2001). The ARDL approach is applicable to a set of time series that are integrated at $\mathrm{I}(1)$ and/or $\mathrm{I}(0)$. Once the cointegration relation is confirmed, the long-run and short-run effect can be estimated by the single equation model. The ARDL bounds testing approach helps to estimate the long-run and short-run relationship between contemporaneous series. In order to estimate equation (1), we apply the ARDL approach by using the specific model of:

$$
\begin{aligned}
\Delta n a r_{t}= & c_{0}+\delta_{1} n a r_{t-1}+\delta_{2} \pi_{t-1}+\sum_{i=1}^{p} \gamma_{i} \Delta n a r_{t-i}+\sum_{j=1}^{q} \psi_{j} \Delta \pi_{t-j}+ \\
& \varphi D U M_{1}+\theta D U M_{2}+\varepsilon_{t}
\end{aligned}
$$

where $c_{0}$ is the constant, $\varepsilon_{t}$ is the error term, $\Delta$ denotes the first difference operator of the respective variable, $n a r_{t}$ is nominal asset return (i.e. $n s r$, $n g r, n r e r, t b y$ and $t b r)$ and $\pi$ is inflation. The inclusion of the dummy variable is based on the information provided by the Bai and Perron (1998) procedure which enabled us to search for a maximum of five structural breaks. Dummy variable $D U M_{1}$ is the Asian financial crisis period and $D U M_{2}$ is the global financial crisis period. The ARDL bounds testing is based on the joint $F$-test for cointegration analysis. In order to find out whether there exists a cointegration between nominal asset returns and inflation in the long-run, we test the null hypothesis of no cointegration among the variables as $\mathrm{H}_{0}: \delta_{1}=\delta_{2}=0$ and the alternative hypothesis as $\mathrm{H}_{1}: \delta_{1} \neq \delta_{2} \neq 0$. Pesaran et al. (2001) reported two sets of critical values for a given significance level. One set of critical value assumes that all variables included in the ARDL model are I(0) while the other set of assumed variables are I(1). If computed that F-statistic is greater than the upper bound critical value, then the null hypothesis is rejected. If the F-statistic is lower than the lower bound critical value, the null hypothesis of no cointegration cannot be rejected. If the null hypothesis is rejected, we can conclude that a long-run relationship exists between nominal asset returns and inflation. The Schwarz Bayesian criterion is used to identify the optimal lag order of the model. If equation (2) estimates reject the null hypothesis of no cointegration, the following unrestricted error correction model is estimated: 


$$
\begin{aligned}
\Delta n a r_{t}= & c_{0}+\sum_{i=1}^{p 1} \xi_{1} \Delta n a r_{t-i}+\sum_{j=1}^{q 1} \omega_{1} \Delta \pi_{t-i}+\gamma E C M_{t-1}+ \\
& \varphi D U M_{1}+\theta D U M_{2}+\varepsilon_{t}
\end{aligned}
$$

where $\xi$ and $\omega$ are short-run dynamic multipliers, and $\mathrm{ECM}_{\mathrm{t}-1}$ is the lagged error-correction term resulting from the long-run equilibrium relationship and $\gamma$ is a parameter indicating the speed of adjustment needed to restore the long-run equilibrium, after a short-run shock. It shows how quickly variables converge to equilibrium but it must have a statistically significant coefficient with a negative sign.

\section{Empirical Results}

\subsection{Unit Root Tests}

Although the ARDL bounds testing method does not require the series to be strictly integrated at $\mathrm{I}(0)$ or $\mathrm{I}(1)$, the stationary of the series cannot go beyond I(1). As a result, the pre-testing of unit root results can be used to confirm the appropriateness of using the ARDL model. To test for the stationary and the order of integration of all series, the ADF and breakpoint unit root test is conducted. Perron and Vogelsang (1992) had mentioned that biases in the traditional unit root test could be reduced by considering an endogenous structural break. Thus, we apply Perron and Vogelsang (1992) and Bai and Perron (1998) tests to test for the presence of a unit root with structural breaks so as to identify the dates of the endogenous structural breaks in our series. The dates of the endogenous breaks obtained from the said tests are, in general, associated with the Asian and/or the Global financial crisis periods. Therefore, we further divide the whole sample period into two sub-periods: Period 1 (1980 Q1 to 1998 Q4) inclusive of the Asian financial crisis and Period 2 (1999 Q1 to 2016 Q4) with the Global financial crisis.

Table 2 presents the results of the unit root with break-point tests for the whole sample period. First, these tests are applied to the level of the variables, then on the first difference of the variables. The results show that all level series are not stationary but their first differences are stationary which suggest that all series are $\mathrm{I}(1)$. This indicates that all series have a unique order of integration, that is I(1). Therefore, none of the variables in this study are I(2). This confirms the appropriateness of using the ARDL analysis. 


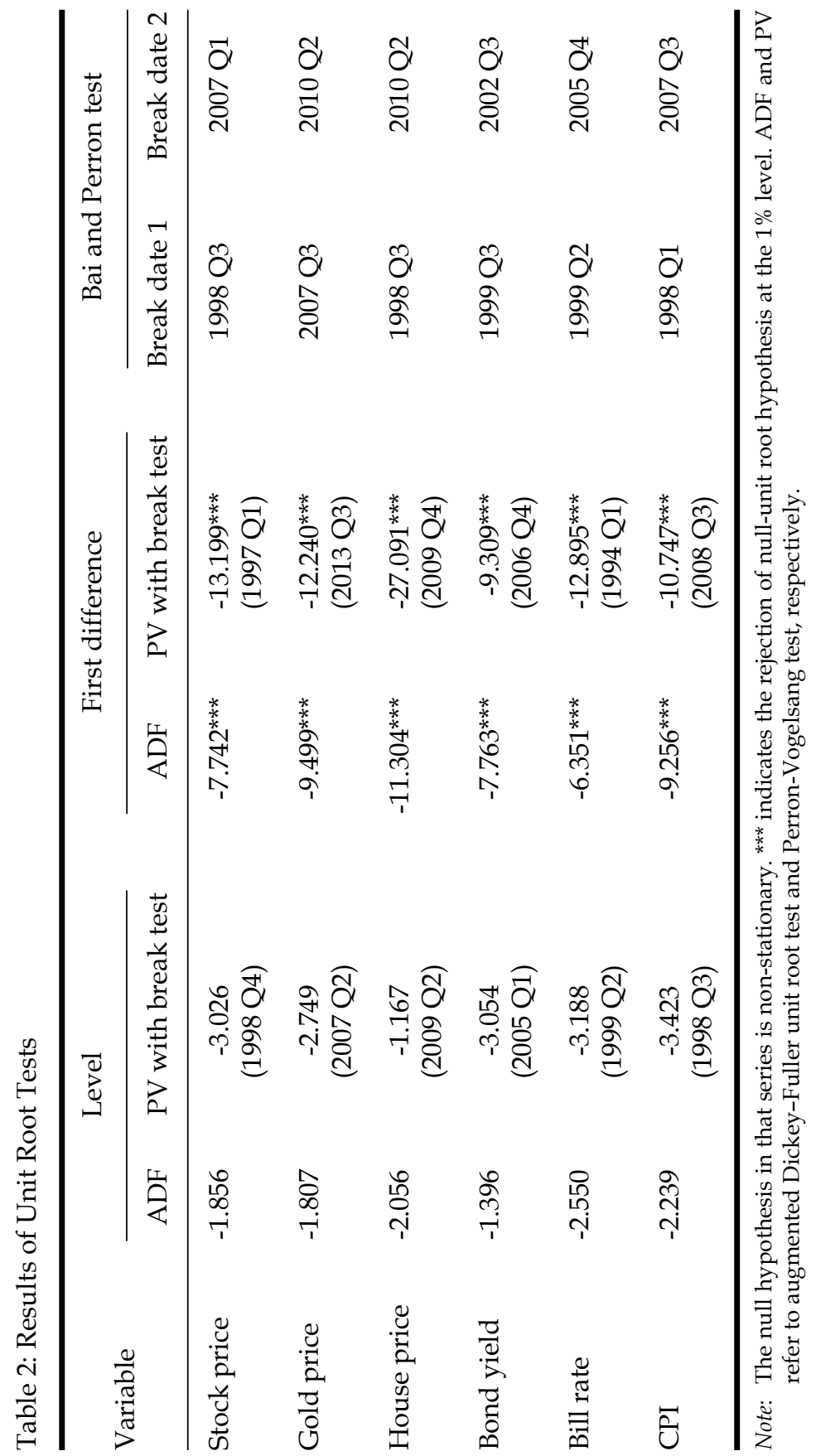




\subsection{ARDL Bounds Testing}

In this section, we examine the ARDL bounds testing for the cointegration between each of the nominal asset returns (i.e. nsr, ngr, nrer, tby and tbr) and inflation. Table 3 presents the results of the ARDL bound tests. The critical values of test statistics suggested by Pesaran et al. (2001), at different levels of significance, are shown in Panel D whereas Panel A shows the results for the whole sample. The ARDL computed F-statistics for each paired-series, except Treasury bill rates and inflation, are greater than the $1 \%$ upper bound critical value. Therefore, the null hypothesis of no cointegration can be rejected. Panel B of Table 3 reports the first sub-period (1980-1998) result which indicated the presence of cointegration between stock returns and inflation and between real estate returns and inflation. There is no cointegration between Treasury bill and inflation. In this sub-period, data for Treasury bond and gold prices are not available. Panel C shows the results for sub-period 2 (1999-2016) which highlighted that the computed F-statistics of all the paired series are above the upper critical value of the bounds test, at least at the $5 \%$ significance level. Hence, we can conclude that cointegration is present between the nominal asset returns of all asset classes and inflation.

\subsection{Estimation of Long-run Parameters}

Following the ARDL cointegration technique performed for the longrun estimates as mentioned above, the next step is to estimate equation (2). Table 4 presents the results. The estimated equations also include two dummy variables, DUM 1 (1997 Q1-1998 Q2) and DUM 2 (2007 Q12008 Q2) to account for the presence of the Asian financial crisis and the Global financial crisis, respectively. To check the robustness of the ARDL model, residual and stability diagnostic tests are applied to each paired series. The residual diagnostic tests consist of Lagrange multiplier (LM) and heteroscedasticity tests while the stability diagnostic tests consist of the Ramsey test and the cumulative sum test for parameter stability (CUSUM). The p-values of the tests indicate no evidence of serial correlation and heteroscedasticity. Further, the p-value of Ramsey's test show no evidence of misspecification of the model. Pesaran et al. (2001) had stated that it is important to ascertain the constancy of the longrun multipliers by testing the error-correction model for the stability of its parameters. To test for the stability of the long-run and short- 
Table 3: Results of ARDL Bounds Testing for Cointegration

\begin{tabular}{|c|c|c|c|c|c|}
\hline Series & $\begin{array}{c}\text { ARDL } \\
\text { cointegration } \\
\text { F-statistics of } \\
\text { bound test }\end{array}$ & Lags & $\begin{array}{c}\text { R- } \\
\text { square }\end{array}$ & $\begin{array}{c}\text { F- } \\
\text { statistics }\end{array}$ & Outcome \\
\hline \multicolumn{6}{|c|}{ Panel A: Whole sample (1980 Q1 to 2016 Q4) } \\
\hline $\begin{array}{l}\text { Nominal stock return } \\
\text { and inflation }\end{array}$ & $66.550 * * *$ & 1,0 & 0.486 & 33.424 & Cointegrated \\
\hline $\begin{array}{l}\text { Nominal real estate } \\
\text { return and inflation }\end{array}$ & $47.163^{* * *}$ & 1,1 & 0.407 & 19.249 & Cointegrated \\
\hline $\begin{array}{l}\text { Treasury bond yield } \\
\text { and inflation }{ }^{1}\end{array}$ & $9.096^{* * *}$ & 2,1 & 0.303 & 5.392 & Cointegrated \\
\hline $\begin{array}{l}\text { Treasury bill rate and } \\
\text { inflation }\end{array}$ & 4.198 & 1,1 & 0.090 & 2.762 & No cointegration \\
\hline \multicolumn{6}{|c|}{ Panel B: Period 1(1980 Q1 to 1998 Q4) } \\
\hline $\begin{array}{l}\text { Nominal stock return } \\
\text { and inflation }\end{array}$ & $36.872^{* * *}$ & 1,0 & 0.482 & 21.173 & Cointegrated \\
\hline $\begin{array}{l}\text { Nominal real estate } \\
\text { return and inflation }\end{array}$ & $24.272^{* * *}$ & 1,0 & 0.396 & 16.181 & Cointegrated \\
\hline $\begin{array}{l}\text { Treasury bill rate and } \\
\text { inflation }\end{array}$ & 3.123 & 1,1 & 0.091 & 1.735 & No cointegration \\
\hline \multicolumn{6}{|c|}{ Panel C: Period 2 (1999 Q1 to 2016 Q4) } \\
\hline $\begin{array}{l}\text { Nominal stock return } \\
\text { and inflation }\end{array}$ & $31.970^{* * *}$ & 1,0 & 0.484 & 21.322 & Cointegrated \\
\hline $\begin{array}{l}\text { Nominal gold return } \\
\text { and inflation }\end{array}$ & $23.571^{* * *}$ & 1,0 & 0.485 & 12.479 & Cointegrated \\
\hline $\begin{array}{l}\text { Nominal real estate } \\
\text { return and inflation }\end{array}$ & $22.363^{* * *}$ & 1,0 & 0.405 & 15.459 & Cointegrated \\
\hline $\begin{array}{l}\text { Treasury bond yield } \\
\text { and inflation }\end{array}$ & $12.513^{* * *}$ & 2,1 & 0.346 & 6.996 & Cointegrated \\
\hline $\begin{array}{l}\text { Treasury bill rate and } \\
\text { inflation }\end{array}$ & $19.133^{* * *}$ & 1,0 & 0.362 & 12.846 & Cointegrated \\
\hline
\end{tabular}

Panel D: Critical value bounds generated by Pesaran et al. (2001)

$\begin{array}{lccc}\text { Significance level } & 10 \% & 5 \% & 1 \% \\ \text { Lower Bounds, I(0) } & 4.04 & 4.94 & 6.84 \\ \text { Upper Bounds, I(1) } & 4.78 & 5.73 & 7.84\end{array}$

Notes: ${ }^{* * *}$ depicts significance at the $1 \%$ level. The critical values for unrestricted intercept and no trend (Case III) are obtained from Pesaran et al. (2001). $\mathrm{H}_{0}$ : no long-run relationship exists, and $\mathrm{H}_{1}$ : long-run relationship exists. In period 1 , for pair series of gold and inflation, and Treasury bond yield and inflation, the result is not shown because data are available only from 2002 and 1990, respectively.

${ }^{1}$ The data series starts in 1996 Q1 to 2016 Q4. 


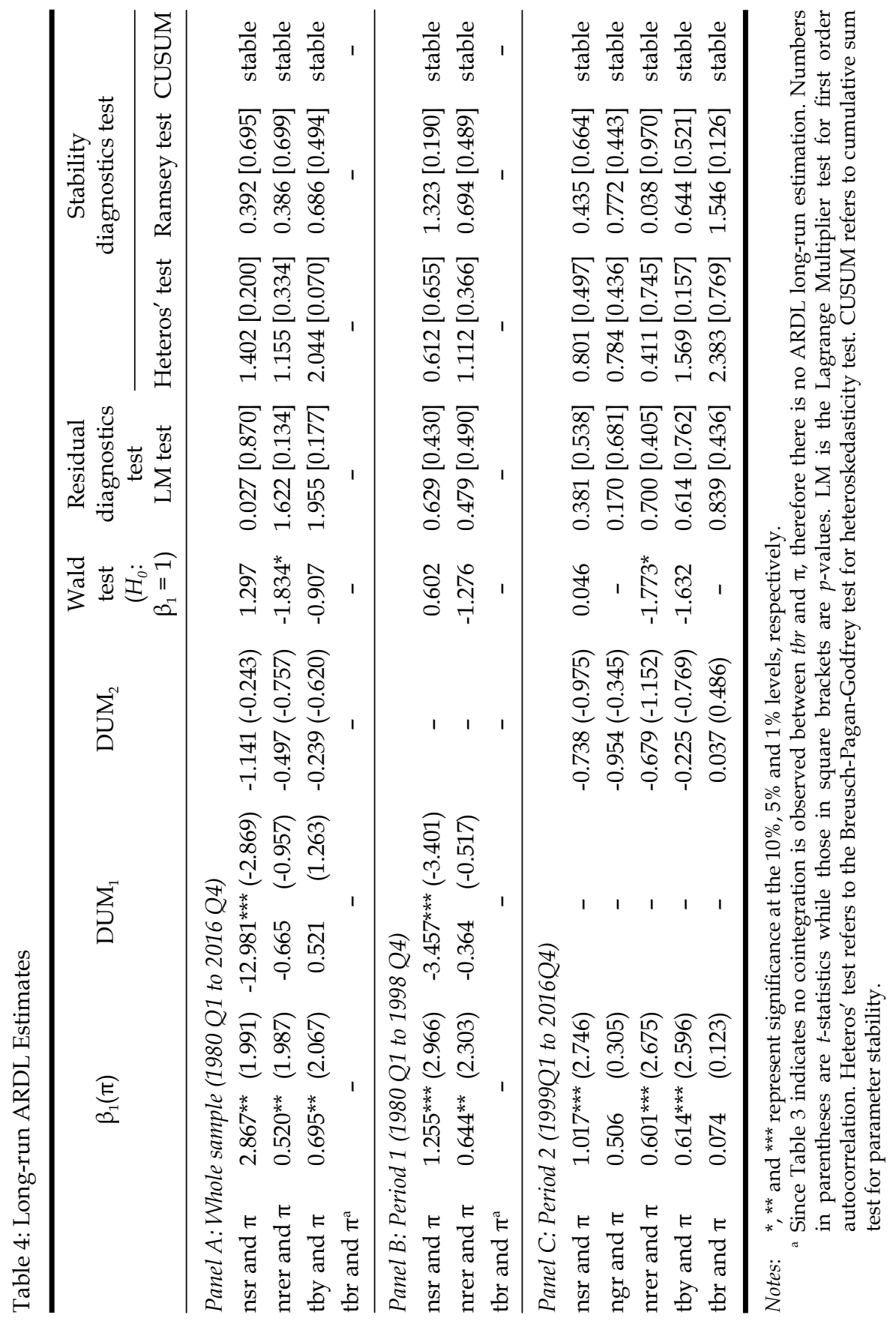


run coefficients estimated by the ARDL model, the cumulative sum (CUSUM) test is engaged. The plots of CUSUM (not shown) are noted to be well within the $5 \%$ critical bounds of parameter stability. This implies that all coefficients in the error correction model are stable.

Table 4 shows that for an asset to be an inflation hedge, $\beta_{1}$ has to be positive. Whether or not it is considered a complete or partial hedge, it is necessary to look at the Wald test. If the Wald test is insignificantly different from unity, the asset is considered a complete hedge against inflation (Arnold \& Auer, 2015). If it is just different from unity, then it is considered a partial hedge.

Panel A of Table 4 shows the results for the whole sample. Here, only three assets are tested for their relationship with inflation: stocks, real estate and bonds. Gold is not included because the data are only available in the second sub-period. Bill rate is not tested because it is found to be not cointegrated with inflation (see Table 3). All the three assets, i.e. stocks, real estate and bonds, are found to have positive coefficients for inflation $\left(\beta_{1}\right)$. This verifies that the three assets are inflation hedges. For stocks and bonds, the Wald test indicates that their $\beta_{1}$ are insignificantly different from 1 . This means that both are considered to provide a complete hedge against inflation. As for real estate, $\beta_{1}$ is significantly different from unity at the $10 \%$ level; therefore, it is considered a partial hedge.

Panel B of Table 4 shows the results for the first sub-period, 19801998. Due to the unavailability of data for gold and bonds and also the absence of cointegration for Treasury bill, only two assets, stocks and real estate, are reported here. The results show that both assets have positive coefficients. The Wald test shows that they are not distinguishable from unity, therefore, these assets are perfect hedges against inflation.

Panel C of Table 4 presents the results of the second sub-period, 1999-2016 which shows that only three assets are positively related with inflation: stocks, real estate and Treasury bond. The Wald test indicates that stocks and bond are a complete hedge against inflation whereas real estate is a partial hedge. Overall, the paired series between stock returns and inflation has the highest coefficient when compared to other paired series for the whole period and the sub-periods. Both gold and Treasury bill are observed to be insignificantly related with inflation, hence they are noted as unable to provide inflation protection to investors. 


\subsection{Estimation of Short-Run Model Parameters}

The previous section has discussed the presence of cointegration which indicates the existence of a long-run relationship. This section supplements the long-run analysis with the error correction analysis (ECM) which looks at the short-run dynamics. Table 5 presents the results of the estimated ECM analysis. It should, however, be noted that only assets that indicate the existence of cointegration is estimated. The lagged error correction term $\left(\mathrm{ECM}_{\mathrm{t}-1}\right)$ shows the speed of adjustment for reestablishing the equilibrium in the dynamic setting. Results in Table 5 further indicate that for all assets, the coefficient of $\mathrm{ECM}_{\mathrm{t}-1}$ shows the expected negative sign which is significant at the $1 \%$ level. This applies to the whole period as well as the sub-periods. A negative coefficient for $\mathrm{ECM}_{\mathrm{t}-1}$ indicates a convergence to long-run equilibrium when there is a shock in the system. The larger the coefficient, the quicker the correction. Looking at the size of the coefficients for the whole sample, it is seen that stock has the largest coefficient of -0.980 , followed by real estate with -0.802 and Treasury bond with -0.124 . This means that for stocks, a shock to the system in one period will result in the correction of about 98 per cent in the following quarter.

The short-run results presented in Table 5 show that the findings are consistent with the results obtained for the long-run. The short-run coefficient for changes in inflation is positive for stocks, real estate and bonds, for all periods. This outcome is consistent with the property of inflation hedges. The coefficient for the Treasury bill is weak while the coefficient for gold is insignificant. Our short-run results are consistent with Shahbaz et al.'s (2016) findings of the stock market in Pakistan, with Akturk's (2016) findings of the Turkish market which showed stock returns to be a good hedge against inflation in the short-run, with the findings of Katrakilidis and Trachanas (2012) who reported that when inflation rises, the house prices in Greece reacted positively in the shortrun and also the findings of Lee (2014) who mentioned that house assets hedge against inflation in the short-run for the Malaysian market.

\subsection{Discussion of Results}

\subsubsection{Stocks}

Of special interest is that our results highlighted that stocks provide a complete hedge against inflation. This result can be considered credible because the results are strongly validated for the whole period as 
Inflation Hedging Properties of Different Asset Classes in Malaysia

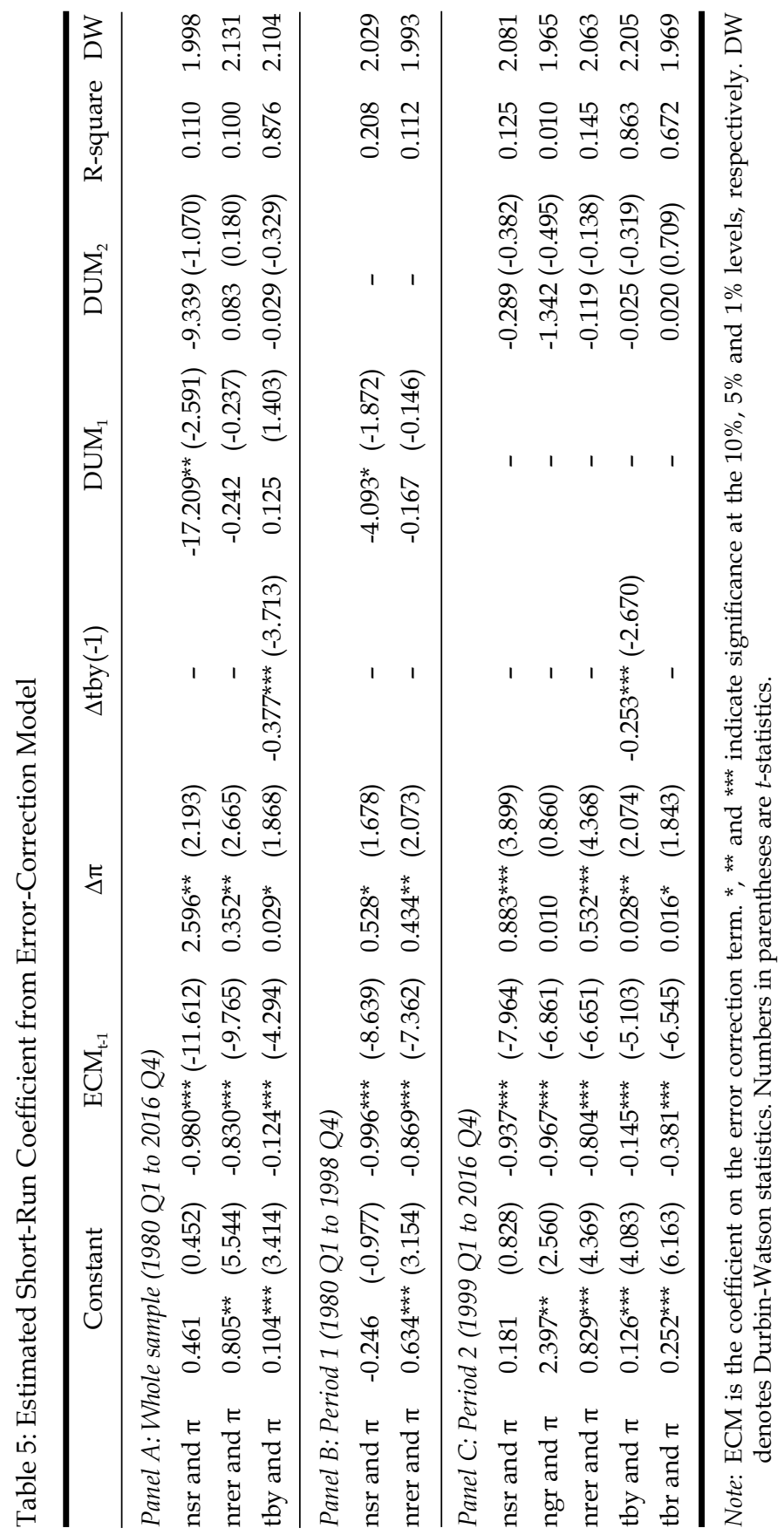


well as the two sub-periods. Our result clearly demonstrate that in both the long-run analysis and the short-run test, there is a rapid oneperiod adjustment occurring in the error correction model. Theoretically, this result is a testimony that the Fisher relationship holds in the context of Malaysia, at least during our study period. From the practical perspective, the finding which shows that stock returns are an inflation hedge is seen as a timely welcome for investors and fund managers. It is comforting to note that their investments would be fully protected against the erosion in purchasing power, thereby protecting real returns.

Our result which notes that stocks can provide a complete hedge against inflation is consistent with many previous studies. For example, Anari and Kolari (2001), Engsted and Tanggaard (2002), and Kim and Ryoo (2011) who observed the US market had reported positive relations exist between stock returns and inflation in the long-run. Our result is also consistent with the outcomes of Ibrahim (2011). The positive relations between stock returns and inflation may be explained as follows. First, the stock prices are driven by a company's future earnings potential which includes inflation expectations together with other elements. Second, equities represent claims against real assets whose values are expected to keep pace with changes in purchasing power (Arnold \& Auer, 2015). Third, during the study period, Malaysia was having a relatively stable inflation rate, hence inflation expectations became more accurate, potentially leading to a better hedging performance.

\subsubsection{Real Estate}

Our results establish that real estate returns provide a partial hedge against inflation. Arnold and Auer (2015) had also stated that even if an asset does not provide a complete hedge, a stable and positive relation with inflation could still make the asset valuable. Real estate is a tangible asset, the increase in the cost of building new houses due to inflationary pressures will result in an increase in the price of existing houses. Consequently, inflation should be positively related to house prices. In the context of Malaysia, real estate has been one of the favourite investment avenues among high net worth individuals. Based on the house price reports, average house price has been on the rise continuously since 2010, at an annual rate of about 10 per cent (global property guide). It is, therefore important for real estate investors to understand their investment behaviour towards inflation. Our results which show that 
real estate prices are positively related with inflation implies that real returns from real estates are not adversely affected by inflation.

Our result showing that real estate acted as a partial inflation hedge is consistent with Anari and Kolari's (2002) outcomes in the US market, Blake et al.'s (2010) results in the UK market and Lee's (2014) findings for the Malaysian market. However, our result is inconsistent with the findings of Yeap and Lean (2017), possibly due to the difference in the study period and the methodology used. Our data ranges from 1980 to 2016, a much longer series than Yeap and Lean's (2017) study; we use the ARDL model whereas Yeap and Lean used the NARDL approach.

\subsubsection{Gold}

In this study, we use the price of the official gold bullion, the Kijang Emas which is issued by the central bank of Malaysia. First issued in 2001, the coin has a purity of 99.99 per cent fine gold and it comes in various denominations. Malaysian bullion coins can be a great way to build a saving because they are considered good, legal tender and they often feature very detailed and visually appealing designs. Maybank is the only distributor for the local gold bullion, on behalf of the central bank. It is possible that the limited supply chain has resulted in an inefficient market which caused the gold price to be unable to respond to the change in inflation.

Our study showing the insignificant relationship between gold returns and inflation is somewhat unexpected because most previous studies had found a positive relationship. Nevertheless, our result is consistent with Mahdavi and Zhou (1997), Tully and Lucy (2007), Wang et al. (2011), Ghazali et al. (2015) and Van Hoang, Lahiani and Heller (2016). It is deduced that the insignificant relationship suggests that gold prices in Malaysia are inefficient for processing relevant information, including inflation. The inefficiency of the gold prices in Malaysia and many other developing countries has also been documented in Ntim, English, Nwachukwu and Wang (2015).

\subsubsection{Government Bond}

Government bonds are long-term securities issued by the Government of Malaysia for financing development expenditures. These securities carry maturities of 3 to 20 years and denominations are RM10 million onwards. The securities are issued through competitive auctions. Since 
these are long-term risk-free securities, it is expected that the yields should be protected against inflation. This is indeed shown by our results, thereby supporting the Fisher relation.

Our result on bond yield and inflation is consistent with many previous studies such as Fama and Schwert (1977), Engsted and Tanggaard (2002) and Laatsch and Klein (2003) who had examined government bonds in the US. The positive relationship shown between bond prices and inflation as noted in our study is explained by the expectation theory of term structure of interest rate. This theory posits that future interest rate is dependent on expected inflation. Another explanation is that long-term sovereign bonds are traded in the international capital markets which are highly efficient in incorporating and reflecting all relevant information, including inflation expectations.

\subsubsection{Treasury Bill}

Treasury bill is a short-term government security issued by the central bank of Malaysia with maturities of less than one year, for working capital. Bills are sold at a discount and payable at face value on maturity. It is a risk-free security and is actively traded in the secondary market. Theoretically, the nominal returns should be strongly related to inflation. It is, therefore quite surprising to see that our results show that Treasury bill and inflation are not cointegrated, therefore unrelated.

Our result showing the lack of Treasury bill returns as inflation hedge is consistent with MacDonald and Murphy (1989), Lee et al. (1998), Engsted and Tanggaard (2002), and Fahmy and Kandil (2003). The insignificant relationship could be attributed to the quarterly data of the 3-month Treasury bill we used which has a relatively short maturity period. Therefore, price changes are relatively small as returns approached the yield of maturity, hence there is no relationship between Treasury bills and inflation.

\section{Conclusion}

This study revisits the Fisher (1930) hypothesis which states that the real rate of return and expected inflation should be independent of each other, thereby resulting in a direct relationship between nominal rates of return and inflation. From the practical perspective, this study has examined the inflation hedging ability of different asset classes which include stock, gold, real estate, Treasury bond and Treasury bill, in the Malaysian context. The bounds testing approach is used to analyse the 
long-run and short-run relation between asset returns and inflation. The ARDL model is used to take into account the long- and shortrun dynamics of the relationship between nominal asset returns and inflation. The ARDL bounds approach has an advantage over other cointegration methods in that it has high statistical power even in small samples (Pesaran et al., 2001). For this study, we used quarterly data that spanned over a 27-year period, 1980 to 2016.

The ARDL bounds test results for each of the paired series show that stock, real estate and Treasury bond are cointegrated with inflation, indicating the existence of a long-run relationship. The Fisher hypothesis is therefore supported. On the practical side, we find that stocks provide a good hedge against inflation, both in the long-run and short-run. This indicates that the Malaysian stock market is efficient in impounding information on inflation expectations into current stock prices. Our results also indicate that real estate and Treasury bond can hedge against inflation to some extent. Our results showing the long-term relationships of these assets and inflation are corroborated by the short-term analysis when using the ECM. Results for gold and Treasury bill show that they do not provide a hedge against inflation. Treasury bill is not cointegrated with inflation while gold tend to show signs of cointegration. The longrun regression shows an insignificant relationship.

This study should interest academics as well as practitioners. From the academic perspective, it provides new evidence on the long-studied Fisher hypothesis. It is interesting to note that the hypothesis is able to withstand the test using new methodology and data. Although not all assets analysed in this study indicate the presence of the Fisher relation, yet in general, the data and methodology employed may be reliably used to make such inferences. From the practical perspective, this study provide important information on the relationship between asset returns and inflation in Malaysia, thereby helping investors and fund managers to manage their asset allocations so that portfolios are free from inflation risks. For example, investors and fund managers who are interested in providing protection to inflation should consider using stocks, real estate and Treasury bond in their investment portfolios. However, our results must be taken with caution. Just like any empirical study, the result discussed in this study is subjected to the data and methodology employed in the analysis and may not be applicable to other periods nor other emerging markets. Future research on inflation hedges may consider a comparative study of a cross-section of countries and use an expanded array of assets in the analysis. 


\section{References}

Aktürk, H. (2016). Do stock returns provide a good hedge against inflation? An empirical assessment using Turkish data during periods of structural change. International Review of Economics \& Finance, 45(September), 230246. http://dx.doi.org/10.1016/j.iref.2016.06.002

Alagidede, P., \& Panagiotidis, T. (2010). Can common stocks provide a hedge against inflation? Evidence from African countries. Review of Financial Economics, 19(3), 91-100. http:// dx.doi.org/10.1016/j.rfe.2010.04.002

Al-Khazali, O. (1999). Nominal interest rates and inflation in the PacificBasin countries. Management Decision, 37(6), 491-498. http://dx.doi.org/ 10.1108/00251749910277989

Anari, A., \& Kolari, J. (2001). Stock prices and inflation. Journal of Financial Research, 24(4), 587-602. http://dx.doi.org/10.1111/j.1475-6803.2001. tb00832.x

Anari, A., \& Kolari, J. (2002). House prices and inflation. Real Estate Economics, 30(1), 67-84. http://dx.doi.org/10.1111/1540-6229.00030

Arnold, S., \& Auer, B.R. (2015). What do scientists know about inflation hedging? The North American Journal of Economics and Finance, 34(November), 187-214. http:// dx.doi.org/10.1016/j.najef.2015.08.005

Aye, G.C., Carcel, H., Gil-Alana, L.A., \& Gupta, R. (2017). Does gold act as a hedge against inflation in the UK? Evidence from a fractional cointegration approach over 1257 to 2016. Resources Policy, 54(December), 53-57. http://dx.doi.org/10.1016/j.resourpol.2017.09.001

Bai, J., \& Perron, P. (1998). Estimating and testing linear models with multiple structural changes. Econometrica, 66(1), 47-78. http://dx.doi. org $/ 10.2307 / 2998540$

Bampinas, G., \& Panagiotidis, T. (2015). Are gold and silver a hedge against inflation? A two century perspective. International Review of Financial Analysis, 41(October), 267-276. http:// dx.doi.org/10.1016/j.irfa.2015.02.007

Beckmann, J., \& Czudaj, R. (2013). Gold and inflation hedge in a time-varying coefficient framework. North American Journal of Economics and Finance, 24(January), 208-222. http://dx.doi.org/10.1016/j.najef.2012.10.007

Blake, N., Goodwin, A., McIntosh, A., \& Simmons, C. (2010). Property and inflation: Research report (IPF Research Programme, 2006-2009). London: Investment Property Forum.

Bodie, Z. (1976). Common stocks as a hedge against inflation. The Journal of Finance, 31(2), 459-470. http://dx.doi.org/10.1111/j.1540-6261.1976. tb01899.x

Boudoukh, J., \& Richardson, M. (1993). Stock returns and inflation: A longhorizon perspective. The American Economic Review, 83(5), 1346-1355.

Brown, K.C., \& Howe, J.S. (1987). On the use of gold as a fixed income security. Financial Analysts Journal, 43(4), 73-76. http://dx.doi.org/10.2469/faj. v43.n4.73 
Chen, M-C., \& Sing, T.F. (2006). Common structural time series components in inflation and residential property prices. Journal of Real Estate Portfolio Management, 12(1), 23-36.

Chu, Y., \& Sing, T.F. (2004). Inflation hedging characteristics of the Chinese real estate market. Journal of Real Estate Portfolio Management, 10(2), 145154.

Chua, J., \& Woodward, R.S. (1982). Gold as an inflation hedge: A comparative study of six major industrial countries. Journal of Business Finance $\mathcal{E}$ Accounting, 9(2), 191-197. http://dx.doi.org/10.1111/j.1468-5957.1982. tb00985.x

Conlon, T., Lucey, B.M., \& Uddin, G.S. (2018). Is gold a hedge against inflation? A wavelet time-scale perspective. Review of Quantitative Finance and Accounting, 51(2), 317-345. http://dx.doi.org/10.1007/s11156-0170672-7

Engsted, T., \& Tanggaard, C. (2002). The relation between asset returns and inflation at short and long horizons. Journal of International Financial Markets, Institutions and Money, 12(2), 101-118. http:/ /dx.doi.org/10.1016/ S1042-4431(01)00052-X

Fahmy, Y.A., \& Kandil, M. (2003). The Fisher effect: New evidence and implications. International Review of Economics $\mathcal{E}$ Finance, 12(4), 451-465. http:/ /dx.doi.org/10.1016/S1059-0560(02)00146-6

Fama, E.F. (1975). Short-term interest rates as predictors of inflation. The American Economic Review, 65(3), 269-282.

Fama, E.F. (1981). Stock returns, real activity, inflation, and money. The American Economic Review, 71(4), 545-565.

Fama, E.F., \& Schwert, G.W. (1977). Asset returns and inflation. Journal of Financial Economics, 5(2), 115-146. http://dx.doi.org/10.1016/0304-405X (77)90014-9

Fang, W-S., Wang, K-M., \& Nguyen, T-B.T. (2008). Is real estate really an inflation hedge? Evidence from Taiwan. Asian Economic Journal, 22(2), 209224. http:/ / dx.doi.org/10.1111/j.1467-8381.2008.00275.x

Fisher, I. (1930). The theory of interest. New York: MacMillan.

Gan, W-B. (1992). Stock returns, inflation, money and economic activity in Malaysia. Asian Economic Journal, 6(1), 1-24. http://dx.doi.org/10.1111/ j.1467-8381.1992.tb00078.x

Geske, R., \& Roll, R. (1983). The fiscal and monetary linkage between stock returns and inflation. The Journal of Finance, 38(1), 1-33. http://dx.doi. org/10.1111/j.1540-6261.1983.tb03623.x

Ghazali, M.F., Lean, H.H., \& Bahari, Z. (2015). Is gold a good hedge against inflation? Empirical evidence in Malaysia. Kajian Malaysia: Journal of Malaysian Studies, 33(1), 69-84.

Ghosh, D., Levin, E.J., Macmillan, P., \& Wright, R.E. (2004). Gold as an inflation hedge? Studies in Economics and Finance, 22(1), 1-25. http://dx.doi. org/10.1108/eb043380 
Gultekin, N.B. (1983a). Stock market returns and inflation forecasts. The Journal of Finance, 38(3), 663-673. http://dx.doi.org/10.1111/j.1540-6261.1983. tb02495.x

Gultekin, N.B. (1983b). Stock market returns and inflation: Evidence from other countries. The Journal of Finance, 38(1), 49-65. http://dx.doi.org/10.1111/ j.1540-6261.1983.tb03625.x

Gunasekarage, A., Power, D.M., \& Zhou, T.T. (2008). The long-term inflation hedging effectiveness of real estate and financial assets: A New Zealand investigation. Studies in Economics and Finance, 25(4), 267-278. http:// dx.doi.org/10.1108/10867370810918155

Ibbotson, R.G., \& Siegel, L.B. (1984). Real estate returns: A comparison with other investments. Real Estate Economics, 12(3), 219-242. http://dx.doi. org/10.1111/1540-6229.00320

Ibrahim, M.H. (2011). Inflation hedging effectiveness of an emerging Asian market: The case of Malaysia. International Journal of Economics and Business Research, 3(5), 514-525. http://dx.doi.org/10.1504/IJEBR.2011.042315

Jaffe, J.F., \& Mandelker, G. (1976). The "Fisher effect" for risky assets: An empirical investigation. The Journal of Finance, 31(2), 447-458. http:// dx.doi.org/10.2307/2326616

Joy, M. (2011). Gold and the US dollar: Hedge or haven? Finance Research Letters, 8(3), 120-131. http:// dx.doi.org/10.1016/j.frl.2011.01.001

Katrakilidis, C., \& Trachanas, E. (2012). What drives housing price dynamics in Greece: New evidence from asymmetric ARDL cointegration. Economic Modelling, 29(4), 1064-1069. http://dx.doi.org/10.1016/j.econmod.2012. 03.029

Kim, J.H., \& Ryoo, H.H. (2011). Common stocks as a hedge against inflation: Evidence from century-long US data. Economics Letters, 113(2), 168-171. http://dx.doi.org/10.1016/j.econlet.2011.07.003

Laatsch, F.E., \& Klein, D.P. (2003). Nominal rates, real rates, and expected inflation: Results from a study of US Treasury Inflation-Protected Securities. The Quarterly Review of Economics and Finance, 43(3), 405-417. http://dx.doi.org/10.1016/S1062-9769(02)00145-X

Lee, C.L. (2014). The inflation-hedging characteristics of Malaysian residential property. International Journal of Housing Markets and Analysis, 7(1), 61-75. http://dx.doi.org/10.1108/IJHMA-10-2012-0053

Lee, C.L., \& Lee, M-L. (2014). Do European real estate stocks hedge inflation? Evidence from developed and emerging markets. International Journal of Strategic Property Management, 18(2), 178-197. http://dx.doi.org/10.3846/ 1648715X.2014.925521

Lee, J-L., Clark, C., \& Ahn, S.K. (1998). Long- and short-run Fisher effects: New tests and new results. Applied Economics, 30(1), 113-124. http://dx.doi. org/10.1080/000368498326209

Levin, E.J., Montagnoli, A., \& Wright, R.E. (2006). Short-run and long-run determinants of the price of gold (Project Report). London: World Gold Council. 
Limmack, R.J., \& Ward, C.W.R. (1988). Property returns and inflation. Land Development Studies, 5(1), 47-55. http://dx.doi.org/10.1080/ 02640828808723945

Lintner, J. (1975). Inflation and security returns. The Journal of Finance, 30(2), 259-280. http://dx.doi.org/10.2307/2978713

MacDonald, R., \& Murphy, P.D. (1989). Testing for the long run relationship between nominal interest rates and inflation using cointegration techniques. Applied Economics, 21(4), 439-447. http://dx.doi.org/10.1080/ 758519711

Mahdavi, S., \& Zhou, S. (1997). Gold and commodity prices as leading indicators of inflation: Tests of long-run relationship and predictive performance. Journal of Economics and Business, 49(5), 475-489. http:// dx.doi.org/10.1016/S0148-6195(97)00034-9

McCown, J.R., \& Zimmerman, J.R. (2006). Is gold a zero-beta asset? Analysis of the investment potential of precious metals. Retrieved from http://dx.doi. org/10.2139/ssrn.920496

Miles, M., \& Mahoney, J. (1997). Is commercial real estate and inflation hedge? Real Estate Finance, 13(Winter), 31-45.

Mishkin, F.S. (1992). Is the Fisher effect for real?: A reexamination of the relationship between inflation and interest rates. Journal of Monetary Economics, 30(2), 195-215. http:/ / dx.doi.org/10.1016/0304-3932(92)90060-F

Nelson, C.R. (1976). Inflation and rates of return on common stocks. The Journal of Finance, 31(2), 471-483. http://dx.doi.org/10.1111/j.1540-6261.1976. tb01900.x

Ntim, C.G., English, J., Nwachukwu, J., \& Wang, Y. (2015). On the efficiency of the global gold markets. International Review of Financial Analysis, 41(October), 218-236.

Perron, P., \& Vogelsang, T.J. (1992). Nonstationarity and level shifts with an application to purchasing power parity. Journal of Business $\mathcal{E}$ Economic Statistics, 10(3), 301-320.

Pesaran, M.H., Shin, Y., \& Smith, R.J. (2001). Bounds testing approaches to the analysis of level relationships. Journal of Applied Econometrics, 16(3), 289326. http://dx.doi.org/10.1002/jae.616

Pimentel, R.C., \& Choudhry, T. (2014). Stock returns under high inflation and interest rates: Evidence from the Brazilian market. Emerging Markets Finance and Trade, 50(1), 71-92. http://dx.doi.org/10.2753/REE1540-496X 500104

Rushdi, M., Kim, J.H., \& Silvapulle, P. (2012). ARDL bounds tests and robust inference for the long run relationship between real stock returns and inflation in Australia. Economic Modelling, 29(3), 535-543. http://dx.doi. org/10.1016/j.econmod.2011.12.017

Shahbaz, M., Islam, F., \& Rehman, I.U. (2016). Stocks as hedge against inflation in Pakistan: Evidence from ARDL approach. Global Business Review, 17(6), 1280-1295. http://dx.doi.org/10.1177/0972150916660393 
Shahbaz, M., Tahir, M.I., Ali, I., \& Rehman, I.U. (2014). Is gold investment a hedge against inflation in Pakistan? A co-integration and causality analysis in the presence of structural breaks. The North American Journal of Economics and Finance, 28(April), 190-205. http://dx.doi.org/10.1016/j. najef.2014.03.012

Smirlock, M. (1986). Inflation announcements and financial market reaction: Evidence from the long-term bond market. The Review of Economics and Statistics, 68(2), 329-333.

Solnik, B., \& Solnik, V. (1997). A multi-country test of the Fisher model for stock returns. Journal of International Financial Markets, Institutions and Money, 7(4), 289-301. http://dx.doi.org/10.1016/S1042-4431(97)00024-3

Tiwari, A.K., Dar, A.B., Bhanja, N., Arouri, M., \& Teulon, F. (2015). Stock returns and inflation in Pakistan. Economic Modelling, 47(June), 23-31. http://dx.doi.org/10.1016/j.econmod.2014.12.043

Tsong, C-C., \& Lee, C-F. (2013). Quantile cointegration analysis of the Fisher hypothesis. Journal of Macroeconomics, 35(March), 186-198. http://dx.doi. org/10.1016/j.jmacro.2012.11.001

Tully, E., \& Lucey, B.M. (2007). A power GARCH examination of the gold market. Research in International Business and Finance, 21(2), 316-325. http://dx.doi.org/10.1016/j.ribaf.2006.07.001

Van Hoang, T.H., Lahiani, A., \& Heller, D. (2016). Is gold a hedge against inflation? New evidence from a nonlinear ARDL approach. Economic Modelling, 54(April), 54-66. http://dx.doi.org/10.1016/j.econmod. 2015.12.013

Wang, K-M., Lee, Y-M., \& Thi, T.B.N. (2011). Time and place where gold acts as an inflation hedge: An application of long-run and short-run threshold model. Economic Modelling, 28(3), 806-819. http://dx.doi.org/10.1016/j. econmod.2010.10.008

Wang, K-M., Lee, Y-M., \& Thi, T.B.N. (2013). Does gold act as inflation hedge in the USA and Japan? Transformations in Business \& Economics, 12(2), 20-43.

Worthington, A.C., \& Pahlavani, M. (2007). Gold investment as an inflation hedge: Co-integration evidence with allowance for endogenous structural breaks. Applied Financial Economics Letters, 3(4), 259-262. http://dx.doi. org/10.1080/17446540601118301

Yeap, G.P., \& Lean, H.H. (2017). Asymmetric inflation hedge properties of housing in Malaysia: New evidence from nonlinear ARDL approach. Habitat International, 62(April), 11-21. http://dx.doi.org/10.1016/j. habitatint.2017.02.006

Zhao, X-Q. (1999). Stock prices, inflation and output: Evidence from China. Applied Economics Letters, 6(8), 509-511. http://dx.doi.org/10.1080/ 135048599352835

Zhou, X., \& Clements, S. (2010). The inflation hedging ability of real estate in China. Journal of Real Estate Portfolio Management, 16(3), 267-277. 